\title{
Serum Levels of Reproductive Hormones and Their Relationship with Age in Men with Benign Prostatic Hyperplasia in Benin City, Edo State
}

\begin{abstract}
Babatunde Ishola Gabriel Adejumo ${ }^{1 *}$, Omolei Lilian Williams ${ }^{1}$, Efosa Bolaji Odigie ${ }^{1}$, Ifeoma Gloria Unachukwu1, Oladimeji Nasiru Abdulrahman², Uchechukwu Dimkpa3 Simon Uzor ${ }^{4}$, Oyarazi Margaret Adebowale5, Ojo Moses Oke ${ }^{6}$
\end{abstract}

${ }^{1}$ Department of Medical Laboratory Science, University of Benin, Benin City, Nigeria

${ }^{2}$ Department of Medical Laboratory Science, College of Health Technology, Offa, Nigeria

${ }^{3}$ Department of Human Physiology, Nnamdi Azikwe University, Nnewi Campus, Nnewi, Nigeria

${ }^{4}$ Department of Applied Science, Faculty of Health and Applied Sciences, University of West of England, Bristol, UK

${ }^{5}$ Department of Virology/Immunology, Federal School of Medical Laboratory Science, Jos, Nigeria

${ }^{6}$ Department of Medical Laboratory Science, College of Health Technology, Akure, Nigeria

Email: ‘babatunde.adejumo@uniben.edu, *bigadejumo@yahoo.com

How to cite this paper: Adejumo, B.I.G., Williams, O.L., Odigie, E.B., Unachukwu, I.G., Abdulrahman, O.N., Dimkpa, U., Uzor, S., Adebowale, O.M. and Oke, O.M. (2020) Serum Levels of Reproductive Hormones and Their Relationship with Age in Men with Benign Prostatic Hyperplasia in Benin City, Edo State. Health, 12, 1121-1131.

https://doi.org/10.4236/health.2020.129082

Received: July 28, 2020

Accepted: September 11, 2020

Published: September 14, 2020

Copyright $\odot 2020$ by author(s) and Scientific Research Publishing Inc. This work is licensed under the Creative Commons Attribution International License (CC BY 4.0).

http://creativecommons.org/licenses/by/4.0/ (c) (i) Open Access

\begin{abstract}
Background: Benign Prostatic Hyperplasia (BPH) is a common condition which occurs as men get older. Aim: We aimed at investigating the reproductive hormone profile of men with BPH and the relationship of these hormones with age. Methods: Twenty-nine men of age $>40$ years were screened for prostate symptoms. The prostate examination included digital rectal examination and measurement of serum prostate-specific antigen levels. Demographic and clinical characteristics of subjects were obtained using a structured questionnaire. The serum levels of Testosterone (Te), Luteinizing hormone (LH), Follicle stimulating hormone (FSH) and Prolactin (PRL) were measured using ELISA method. Results: Our study indicated that age and levels of prostate specific antigen (PSA), LH and FSH were significantly ( $\mathrm{p}<$ 0.05) higher in men with BPH compared with healthy controls. In contrast, the control group indicated significantly $(\mathrm{p}<0.05)$ higher Te level compared with the BPH group. In patients with $\mathrm{BPH}$, age was significantly $(\mathrm{p}<0.05)$ correlated with the hypothalamic-pituitary-testicular axis hormones ( $\mathrm{LH}, \mathrm{FSH}$ and PRL), but not with the sex hormone, and testosterone. Majority (62.1\%) of the patients with BPH indicated they had poor libido, while none of them indicated regular sexual activity with their spouses. Conclusion: This study suggests that the rise in serum levels of the hypothalamic-pituitary-testicular axis
\end{abstract}


hormones in $\mathrm{BPH}$ patients as demonstrated by the present findings may be age-related since testicular dysfunction in aging men is associated with the decrease in androgen production which may stimulate an increased production of gonadotropins by negative feedback.

\section{Keywords}

Hormones, Age, Men, Prostate, Hyperplasia

\section{Introduction}

Benign prostatic hyperplasia ( $\mathrm{BPH}$ ), also called prostate enlargement, is a noncancerous increase in size of the prostate gland resulting in bladder outlet obstruction and lower urinary tract symptoms such as frequent urination, urinary urgency, trouble starting to urinate, weak stream, dribbling at the end of urination, nocturia, urinary incontinence and inability to urinate [1]. According to the National Institute of Diabetes and Digestive and Kidney Diseases approximately $50 \%$ of men aged $51-60$ years and nearly $90 \%$ of men over 80 years of age are living with this condition [1].

The cause of BPH is not well understood. However, aging and hormonal alterations and factors relating to the testes appear to be the main factors responsible for the development of BPH [2]. Age has been proved to play a role in the progressive development of pathologic and clinical $\mathrm{BPH}$ as virtually all men present with histological BPH as they grow [3] [4]. Age itself seems to increase the risk of BPH through changes in the endocrine environment, which leads to an imbalance between stimulatory and inhibitory growth factors [5]. It is well established that androgens are essential for prostate development and play a major role in the pathophysiology of BPH [2].

Little is known about the role of the hormones of the hypothalamic-pituitarygonadotropic axis on the effect of benign prostatic enlargement. However, testosterone synthesis and male fertility are controlled by the perfect coordination of the hypothalamic-pituitary-gonadal axis through a negative feedback mechanism [6]. The hypothalamus secretes gonadotrophin releasing hormone (GnRH) in a pulsatile fashion, which stimulates the anterior pituitary gland to secrete two hormones vital for reproduction, follicle-stimulating hormone (FSH) and luteinizing hormone (LH), as well as adrenocorticotropin, growth hormone, prolactin, and thyroid-stimulating hormone [7]. Luteinizing hormone and FSH act on cells in the testes including Leydig, Sertoli and germ cells to produce testosterone, inhibin B and androgen-binding protein [6].

The role of age-related serum hormones, including the androgens and gonadotropins, in patients with $\mathrm{BPH}$, is far from a complete understanding and requires further investigation. It is therefore imperative to improve our understanding of the hormonal profile of men with $\mathrm{BPH}$ and the relationship between 
age and the hormones from hypothalamic pituitary-testicular axis in men with $\mathrm{BPH}$. We therefore aimed at investigating the reproductive hormone profile of men with BPH and the relationship of these hormones with age.

\section{Methodology}

\subsection{Subjects}

A total of 59 male participants (29 patients with BPH and 30 healthy controls) of age $\geq 40$ years were included in this study. The patients with BPH were recruited from Urology Clinic at Central Hospital, Benin City, while the controls were recruited at different locations in Benin City. Prostate examination involving digital rectal examination and measurement of serum PSA levels was conducted in the Urology Clinic at Central Hospital, Benin City to determine men with BPH. Men with abnormal findings by rectal examination or an elevated serum PSA level $(4.0 \mathrm{ng} / \mathrm{mL})$ were referred for prostate biopsy to exclude the possibility of prostate cancer. Demographic characteristics and detailed medical history, particularly about chronic systemic diseases such as diabetes mellitus and hypertension, smoking and drinking habits, age at first sexual intercourse, urinary tract symptoms, current medications, family history of BPH, frequency of sexual intercourse and current rating of libido were obtained from all patients using structured questionnaires. Informed consents were obtained from each participant after proper notification and information on the nature of the research, the benefits and risks involved as well as confidentiality. Ethics and research committee of Ministry of Health, Benin City approved this work with reference number HM.1208/7458. Subjects with a known history of endocrine diseases, including hypogonadism, previous Te substitutive therapy and/or hormonal manipulation (including $5 \alpha$-reductase inhibitors, androgen receptor blockers and LHreleasing hormone analogues), and those of age $<40$ years were excluded from the study. The adjunctive exclusion criteria were a classification of Eastern Cooperative Oncology Group (ECOG) grade > 1, previous radiation therapy and chronic ingestion of alcohol or other drugs, including steroids, barbiturates, spironolactone and cimetidine, that may have interfered with the serum hormone levels.

\subsection{Hormonal Measurements}

Blood samples were collected by venipuncture between 8:00 and 11:00 a.m.to minimize the effects of diurnal variation. Serum Testosterone, LH, FSH and PRL levels were determined by ELISA method from Calibiotech ELISA kits (Te, LH, FSH and PRL), CA 92020, USA, according to manufacturer's instructions.

\subsection{Data Analysis}

Data was expressed as mean \pm standard deviation or median (percentile 25 - 75) for continuous data and percentages for categorical variables. Comparative analysis between the control and the $\mathrm{BPH}$ group data was done using non-parametric 
Mann-Whitney U test. Correlation tests involving two variables were done using the Spearman's Rank Correlation Coefficient. Test of significance was set at $\mathrm{p}<$ 0.05. All statistics were done using SPSS/IBM Software (version 20).

\section{Results}

The demographic and baseline characteristics of the study population are expressed in Table 1. Mann-Whitney test shows that men with BPA were older and indicated a significantly higher PSA level compared with healthy control ( $\mathrm{p}$ $<0.001$, respectively). Majority of the $\mathrm{BPH}$ patients were of age $61-70$ years $(48.3 \%)$, while the control group was dominated by those aged $\leq 60$ years $(80 \%)$. There were higher percentages of participants (control, 96.7\%; BPH patients, $48.3 \%$ ) whose PSA levels fell within $0-2.4 \mathrm{ng} / \mathrm{mL}$. Most of the subjects in control group were civil servants (86.7\%), while retirees (37.9\%) dominated the BPH group population. A greater percentage of the study population ( $\mathrm{BPH}$ patients, 100\%; control, 76.7\%) were married.

Table 2 shows selected clinical characteristics of the patients with BPH at baseline. The subjects were non-smokers, non-drinkers and did not indicate presence of blood in their urine. Majority of the patients had their first sexual experience at $>20$ years of age $(69 \%)$, had difficulty urinating $(89.7 \%)$, had no

Table 1. Demographic and baseline characteristics of the study population.

\begin{tabular}{ccccc}
\hline Characteristics & $\begin{array}{c}\text { Control, } \mathbf{n}=\mathbf{3 0} \\
\text { Mean } \pm \text { SD or } \mathbf{n}(\%)\end{array}$ & $\begin{array}{c}\text { Men with BPH, } \mathbf{n}=\mathbf{2 9} \\
\text { Mean } \pm \text { SD or } \mathbf{n}(\%)\end{array}$ & z & p Value \\
\hline Age (yrs) & $46.9 \pm 12.5$ & $66.5 \pm 10.4$ & & \\
$\leq 60$ & $24(80.0)$ & $8(27.6)$ & -5.15 & $<0.001$ \\
$61-70$ & $5(16.7)$ & $14(48.3)$ & \\
$\geq 71$ & $1(3.3)$ & $7(24.1)$ & \\
PSA (ng/mL) & $0.14 \pm 0.74$ & $12.1 \pm 25.3$ & \\
$0-2.4^{*}$ & $29(96.7)$ & $14(48.3)$ & \\
$2.5-3.9^{*}$ & $0(0)$ & $3(10.3)$ & \\
$4-10.0^{*}$ & $0(0)$ & $4(13.8)$ & \\
$>10.0^{*}$ & $1(3.3)$ & $8(27.6)$ & \\
Occupation $_{\text {Businessmen }}^{*}$ & $2(6.7)$ & & \\
Civil Servants $^{*}$ & $26(86.7)$ & $1(3.4)$ & \\
Farmers $^{*}$ & $0(0)$ & $8(27.5)$ & \\
Retirees $^{*}$ & $0(0)$ & $6(20.7)$ & \\
Unemployed $^{*}$ & $0(0)$ & $11(37.9)$ & \\
Unskilled $^{*}$ & $1(3.3)$ & $3(10.3)$ & \\
Marital Status $^{*}$ & $7(23.3)$ & $0(0)$ & \\
Married $^{*}$ & $23(76.7)$ & $0(0)$ & \\
Single $^{*}$ & & & \\
\hline
\end{tabular}

Abbreviations and symbols: SD, standard deviation; $n$ (\%), Number of participants (percentage). PSA, Prostate Specific Antigen; ${ }^{\ddagger}$ Mean $\pm \mathrm{SD} ;{ }^{\star} \mathrm{n}(\%)$. 
Table 2. Selected clinical characteristics of the patients with BPH at baseline.

\begin{tabular}{|c|c|c|}
\hline Characteristics & Number of Subjects & Percentage \\
\hline \multicolumn{3}{|l|}{ Smoking Habit } \\
\hline Smokers & 0 & 0 \\
\hline Non-smokers & 29 & 100 \\
\hline \multicolumn{3}{|l|}{ Drinking Habit } \\
\hline Current drinkers & 0 & 0 \\
\hline Non-drinkers & 29 & 100 \\
\hline \multicolumn{3}{|l|}{ Age of $1^{\text {st }}$ Sexual Intercourse } \\
\hline$\leq 20 \mathrm{yrs}$ & 9 & 31.0 \\
\hline$>20 \mathrm{yrs}$ & 20 & 69.0 \\
\hline Can't Remember & 0 & 0 \\
\hline \multicolumn{3}{|l|}{ Difficulty Urinating } \\
\hline No & 3 & 10.3 \\
\hline Yes & 26 & 89.7 \\
\hline \multicolumn{3}{|l|}{ Presence of Blood Urine } \\
\hline No & 29 & 100 \\
\hline Yes & 0 & 0 \\
\hline \multicolumn{3}{|c|}{ Family History of Prostate Enlargement } \\
\hline No & 21 & 72.4 \\
\hline Yes & 5 & 17.2 \\
\hline No Idea & 3 & 10.3 \\
\hline \multicolumn{3}{|l|}{ Medication } \\
\hline None & 20 & 68.9 \\
\hline Yes & 9 & 31.1 \\
\hline No Response & 0 & 0 \\
\hline \multicolumn{3}{|c|}{ Frequency of Sexual Intercourse (per month) } \\
\hline Zero (None) & 4 & 13.8 \\
\hline 1 - 2 times (Rarely) & 13 & 44.8 \\
\hline 3 - 4 times (Occasionally) & 12 & 41.4 \\
\hline$\geq 5$ times (Regular) & 0 & 0 \\
\hline \multicolumn{3}{|l|}{ Current Libido } \\
\hline Poor & 18 & 62.1 \\
\hline Fair & 3 & 10.3 \\
\hline Good & 8 & 27.6 \\
\hline
\end{tabular}

family history of $\mathrm{BPH}(72.4 \%)$, and were not currently taking any medications for symptoms associated with BPH (68.9\%). A greater percentage (44.8\%) rarely had sex, while none of the men indicated having regular sexual intercourse with their spouse or partners. Majority of the patients indicated they had poor libido, while $27.6 \%$ stated they had good libido.

The serum testosterone, LH and FSH levels in men with $\mathrm{BPH}$ in comparison 
with healthy control are shown in Table 3. Mann-Whitney $U$ test indicated a significantly greater FSH $(\mathrm{p}=0.003), \mathrm{LH}(\mathrm{p} \leq 0.001)$ and PRL $(\mathrm{p}<0.001)$ levels in men with BPH compared with the control group. On the other hand, the control group indicated significantly $(\mathrm{p}=0.019)$ higher Te level compared with the BPH group.

The distribution of sex hormone levels by age group of patients with benign prostatic hyperplasia is shown in Table 4. Data show steady decline in testosterone level as age increases. On the other hand, LH, FSH and PRL levels indicated linear increases with increase in age.

Table 5 shows the correlation test between age and the reproductive hormones in men with benign prostatic hyperplasia. Spearman ranking test indicated significant positive associations between age and FSH $(p=0.001), \mathrm{LH}(\mathrm{p}=$

Table 3. Serum testosterone, LH and FSH levels in men with benign prostatic hyperplasia.

\begin{tabular}{|c|c|c|c|c|}
\hline Hormones & $\begin{array}{c}\text { Control, } \\
\mathrm{n}=30\end{array}$ & $\begin{array}{c}\text { Men with BPH, } \\
\quad \mathrm{n}=29\end{array}$ & $\mathbf{z}$ & $\mathrm{p}$ Value \\
\hline \multicolumn{5}{|l|}{$\mathrm{Te}(\mathrm{ng} / \mathrm{mL})$} \\
\hline Median (percentile 25 - 75) & $4.4(2.5-5.7)$ & $3.0(1.1-4.4)$ & \multirow{3}{*}{-2.33} & \multirow{3}{*}{0.019} \\
\hline Mean \pm SD & $5.10 \pm 3.92$ & $3.17 \pm 2.79$ & & \\
\hline Mean Rank & 35.13 & 24.69 & & \\
\hline \multicolumn{5}{|l|}{$\mathrm{FSH}(\mathrm{mIU} / \mathrm{mL})$} \\
\hline Median (percentile 25 - 75) & $14.2(9.8-20.1)$ & $23.1(14.2-76.1)$ & \multirow{3}{*}{-2.98} & \multirow{3}{*}{0.003} \\
\hline Mean \pm SD & $16.66 \pm 9.15$ & $43.83 \pm 38.52$ & & \\
\hline Mean Rank & 23.43 & 36.79 & & \\
\hline \multicolumn{5}{|l|}{$\mathrm{LH}(\mathrm{mIU} / \mathrm{mL})$} \\
\hline Median (percentile 25 - 75) & $5.9(3.6-7.3)$ & $10.1(6.6-14.7)$ & \multirow{3}{*}{-3.54} & \multirow{3}{*}{$<0.001$} \\
\hline Mean \pm SD & $5.56 \pm 2.77$ & $12.92 \pm 12.13$ & & \\
\hline Mean Rank & 22.22 & 38.05 & & \\
\hline \multicolumn{5}{|l|}{ PRL (ng/mL) } \\
\hline Median (percentile 25 - 75) & $0(0-0.55)$ & $21.0(13.3-24.3)$ & \multirow{2}{*}{-6.77} & \multirow{2}{*}{$<0.001$} \\
\hline Mean \pm SD & $0.26 \pm 0.47$ & $31.79 \pm 40.19$ & & \\
\hline Mean Rank & 15.50 & 45.0 & & \\
\hline
\end{tabular}

Abbreviations: SD, Standard deviation; Te, Testosterone; FSH, Follicle stimulating hormone; LH, Luteinizing hormone; PRL, Prolactin.

Table 4. Mean \pm SD of the reproductive hormones according to age classifications of patients with benign prostatic hyperplasia.

\begin{tabular}{cccccc}
\hline Age Groups $(\mathrm{yrs})$ & $\mathrm{n}$ & $\mathrm{Te}(\mathrm{ng} / \mathrm{mL})$ & $\mathrm{LH}(\mathrm{mIU} / \mathrm{mL})$ & FSH $(\mathrm{mIU} / \mathrm{mL})$ & PRL $(\mathrm{ng} / \mathrm{mL})$ \\
\hline$\leq 60$ & 8 & $4.27 \pm 2.19$ & $9.27 \pm 5.38$ & $16.43 \pm 10.43$ & $21.97 \pm 10.25$ \\
$61-70$ & 14 & $3.34 \pm 3.23$ & $12.07 \pm 6.87$ & $47.04 \pm 33.28$ & $30.50 \pm 37.48$ \\
$\geq 71$ & 7 & $1.58 \pm 1.88$ & $18.78 \pm 22.16$ & $68.71 \pm 51.50$ & $45.61 \pm 63.37$ \\
\hline
\end{tabular}

Abbreviations: SD, Standard deviation; Te, Testosterone; FSH, Follicle stimulating hormone; LH, Luteinizing hormone; PRL, Prolactin. 
Table 5. Relationship between age and reproductive hormones in men with benign prostatic hyperplasia.

\begin{tabular}{cccc}
\hline Age vs. & $\mathbf{n}$ & Coefficient $(\mathbf{r})$ & p Value \\
\hline Te & 29 & -0.275 & 0.149 \\
FSH & 29 & 0.605 & 0.001 \\
LH & 29 & 0.409 & 0.028 \\
PRL & 29 & 0.370 & 0.048 \\
\hline
\end{tabular}

Data presented as Spearman's Rank Correlation Coefficient. Abbreviations: Te, Testosterone; FSH, Follicle stimulating hormone; LH, Luteinizing hormone; PRL, Prolactin; r, Correlation coefficient.

$0.028)$, and PRL ( $\mathrm{p}=0.048)$. In contrast, non-significant negative correlation was observed between age and testosterone level $(r=-0.275 ; p=0.149)$.

\section{Discussion}

The present study had several important findings. Age and levels of PSA, LH and FSH were significantly higher in men with BPH compared with healthy controls. In contrast, the control group indicated significantly higher Te level compared with the $\mathrm{BPH}$ group. In patients with $\mathrm{BPH}$, age was significantly associated with the hypothalamic-pituitary-testicular axis hormones (LH, FSH and PRL), but not with the sex hormone, testosterone. Majority (62.1\%) of the patients with BPH indicated they had poor libido, while none of them indicated regular sexual activity with their spouses.

Age is the primary etiologic factor that is largely accepted to play a role in the pathogenesis of $\mathrm{BPH}$ [8]. The present result in which men with $\mathrm{BPH}$ were significantly of greater age than their control is therefore in agreement with the established fact that the incidence of $\mathrm{BPH}$ is a disease that develops in men as they age; approximately $50 \%$ of men aged 51 - 60 years and nearly $90 \%$ of men over 80 years of age are living with this condition [3]. Age has been proved to play a role in the progressive development of pathologic and clinical BPH as virtually all men present with histological BPH as they grow [4]. Furthermore, the diagnosis of benign prostatic hyperplasia is most often based on symptoms such as abnormally high blood PSA level. In this study, we observed a higher serum level of PSA in patients with BPH compared with the healthy control. Prostate volume has also been strongly related to serum PSA in men with BPH [9].

It is well established that androgens are essential for prostate development and play a major role in the pathophysiology of BPH [2]. The results of the present study which indicated significantly lower testosterone levels in men with BPH compared with the healthy controls, is in contrast with previous studies which found no significant difference in serum Te between control subjects and men with BPH [10] [11]. In another study involving African-American men, it was found that that large prostrate volume was marginally associated with increased total testosterone levels [12]. Furthermore, a previous study did not indicate any significant correlation in serum testosterone level and prostate volume in co- 
horts with $\mathrm{BPH}$ [13].

Little is known with regard to the effect of benign prostatic enlargement on the hypothalamic-pituitary hormone axis. However, it is known that LH and FSH are involved in enhancing the production of androgens by stimulation of Leydig cells to produce testosterone and the production of androgen-binding protein by the Sertoli cells of the testes respectively [6]. Physiologic levels of prolactin in males have also been shown to enhance luteinizing hormone-receptors in Leydig cells, resulting in testosterone secretion, which leads to spermatogenesis [14]. On the other hand, elevated levels of prolactin have been reported to decrease the levels of sex hormones-estrogen in women and testosterone in men [15]. The present study indicated significantly higher levels of the gonadotropins (LH, FSH) and PRL in the BPH patients compared with the control. Our findings agree with a previous study which reported significant increase in serum LH and FSH levels with increase in measures of BPH [16]. It is thought that the rise in serum gonadotropin levels as seen in this study may be age-related since testicular dysfunction in aging men is associated with the decrease in androgen production, which may stimulate an increased production of gonadotropins by negative feedback [12]. Furthermore, we found significantly higher values of PRL in BPH compared with the control. This is in disagreement with previous studies which have previously demonstrated no significant relationships between PRL and measures of BPH [12]. Nevertheless, there is a growing evidence to show that PRL stimulates proliferation and differentiation of prostatic epithelial cells [17] [18]. Several studies [19] [20] [21], on rodent models which have demonstrated over-expression of PRL suggest the involvement of PRL in BPH. However, there are no data so far indicating a direct role for PRL in BPH in humans.

In order to understand the effect of the age-related $\mathrm{BPH}$ on the hormones of the hypothalamo-pituitary-testicular axis, we sought to investigate the relationship between age and levels of testosterone, LH, FSH and PRL. We believe this will help in elucidating the complex endocrinology of aging men prone to $\mathrm{BPH}$ and the physiology of reproductive capacity, and clinically assessment of sexual functions such as loss of libido or decreased sexual performance among men with $\mathrm{BPH}$. The present study indicated that there was no significant association between age and total testosterone level, even when negative correlation was established. In contrast, there were significant positive correlations between age and LH, FSH and PRL. It has been previously established that testosterone decline, whereas LH, FSH rise with increase in age [22].

A previous study indicated a rise in serum prolactin with increasing age in men [23], where as another study [24] indicated no age effect on PRL. It is however not clear whether the relationship between age and testosterone is universal or inevitable. For example, other studies have shown that testosterone levels may not vary with age or even increase with age in some men [25] [26]. The lack of significant association between age and testosterone observed in this study may be explained by the fact that many of the older men in this study had levels of 
testosterone similar to those observed in younger men.

Our result is in agreement with already established fact that the pituitary gonadotrophins, LH and FSH increase with age in men [22]. The rise in FSH and $\mathrm{LH}$ with increasing age is consistent with the decline in testosterone, assuming normal operation of the feedback pathway by which low testosterone level signals the hypothalamic-pituitary axis to release FSH and $\mathrm{LH}$ [27]. The implication of this is that aging effects on testicular function may be compensated by increases in $\mathrm{LH}$ and FSH.

It is noteworthy, that none of the men with $\mathrm{BPH}$ indicated regular sexual activity with their spouses. Similarly, majority $(62.1 \%)$ of the patients with $\mathrm{BPH}$ indicated poor current libido. It is not clear if these poor sexual functions in men with $\mathrm{BPH}$ are age related or associated with their reproductive hormonal profile or other underlying non-hormonal factors that may inhibit or attenuate sexual functions. This calls for further studies to elucidate these facts.

A potential limitation of the present study is the relatively small sample size and our inability to assay free or bioavailable testosterone, or sex hormone-binding globulin which were excluded due to their cost.

\section{Conclusion}

The present study indicated that $\mathrm{BPH}$ is associated with increase in $\mathrm{LH}, \mathrm{FH}$ and PRL levels, and a decline in testosterone level. The significant positive correlations observed between age and LH, FSH and PRL suggest that the rise in serum gonadotropin levels as seen in this study may be age-related since testicular dysfunction in aging men is associated with the decrease in androgen production which may stimulate an increased production of gonadotropins by negative feedback. More studies are needed to further unravel, the complex endocrinology of aging men prone to $\mathrm{BPH}$ in order to assess the decline in sexual performance in men with $\mathrm{BPH}$.

\section{Conflicts of Interest}

The authors declare no conflicts of interest regarding the publication of this paper.

\section{References}

[1] U.S. Department of Health and Human Services-National Institute of Diabetes and Digestive and Kidney Diseases (2014) Prostate Enlargement (Benign Prostatic Hyperplasia). NIDDK.

http://www.niddk.nih.gov/health-information/urologic-diseases/prostate-problems/ prostate-enlargement-benign-prostatic-hyperplasia

[2] Nicholson, T.M. and Ricke, W.A. (2011) Androgens and Estrogens in Benign Prostatic Hyperplasia: Past Present and Future. Differentiation, 82, 184-199. https://doi.org/10.1016/j.diff.2011.04.006

[3] Berry, S.J., Coffey, D.S., Walsh, P.C. and Ewing, L.L. (1984) The Development of Human Benign Prostatic Hyperplasia with Age. Journal of Urology, 132, 474-479. 
https://doi.org/10.1016/S0022-5347(17)49698-4

[4] Briganti, A., Capitanio, U., Suardi, N., Gallina, A., Salonia, A., Bianchi, M., et al. (2009) Benign Prostatic Hyperplasia and Its Aetiologies. European Urology Supplements, 8, 865-871. https://doi.org/10.1016/j.eursup.2009.11.002

[5] Griffiths, K., Cockett, A.T., Coffey, D., et al. (1998) Regulation of Prostate Growth. In: Denis, L., Grriffiths, K. and Khoury, S., Eds., The 4th International Consultation on Benign Prostatic Hyperplasia, Health Publications, Plymouth, 83-128.

[6] Corradi, P.F., Corradi, R.B. and Greene, L.W. (2016) Physiology of the Hypothalamic Pituitary Gonadal Axis in the Male. Urologic Clinic, 43, 151-162.

https://doi.org/10.1016/j.ucl.2016.01.001

[7] Sussman, E.M., Chudnovsky, A. and Niederberger, C.S. (2008) Hormonal Evaluation of the Infertile Male: Has It Evolved? Urologic Clinics of North America, 35, 147-155. https://doi.org/10.1016/j.ucl.2008.01.010

[8] Partin, A.W., Oesterling, J.E., Epstein, J.I., Horton, R. and Walsh, P.C. (1991) Influence of Age and Endocrine Factors on the Volume of Benign Prostatic Hyperplasia. Journal of Urology, 145, 405-409. https://doi.org/10.1016/S0022-5347(17)38353-2

[9] Roehrborn, C.G., Boyle, P., Gould, A.L. and Waldstreicher, J. (1999) Serum Prostate-Specific Antigen as a Predictor of Prostate Volume in Men with Benign Prostatic Hyperplasia. Urology, 53, 581-589. https://doi.org/10.1016/S0090-4295(98)00655-4

[10] Rohrmann, S., Nelson, W.G., Rifai, N., Kanarek, N., Basaria, S., et al. (2007) Serum Sex Steroid Hormones and Lower Urinary Tract Symptoms in Third National Health and Nutrition Examination Survey (NHANES III). Urology, 69, 708-713. https://doi.org/10.1016/j.urology.2007.01.011

[11] Roberts, R.O., Jacobson, D.J., Rhodes, T., Klee, G.G., Leiber, M.M., et al. (2004) Serum Sex Hormones and Measures of Benign Prostatic Hyperplasia. Prostate, 61, 124-131. https://doi.org/10.1002/pros.20080

[12] Joseph, M.A., Wei, J.T., Harlow, S.D., Cooney, K.A., Dunn, R.L., et al. (2002) Relationship of Serum Sex Steroid Hormones and Prostate Volume in African-American Men. Prostate, 53, 322-329. https://doi.org/10.1002/pros.10154

[13] Zeng, Q., Xu, C., Liu, Z.-Y., Wang, H., Yang, B. and Xu, W. (2012) Relationship between Serum Sex Hormones Levels and Degree of Benign Prostate Hyperplasia in Chinese Aging Men. Asian Journal of Andrology, 14, 773-777.

https://doi.org/10.1038/aja.2012.32

[14] Hair, W.M., Gubbay, O., Jabbour, H.N. and Lincoln, G.A. (2002) Prolactin Receptor Expression in Human Testis and Accessory Tissues: Localization and Function. Molecular Human Reproduction, 8, 606-611. https://doi.org/10.1093/molehr/8.7.606

[15] Mayo Clinic Staff (2020) Prolactinoma-Symptoms and Causes. Mayo Foundation for Medical Education and Research. http://www.mayoclinic.org/diseases-conditions/prolactinoma/symptoms-causes/syc $-20376958$

[16] Gray, A., Feldman, H.A., McKinlay, J.B. and Longcope, C. (1991) Age, Disease, and Changing Sex Hormone Levels in Middle-Aging Men: Results of the Massachusetts Male Aging Study. The Journal of Clinical Endocrinology \& Metabolism, 73, 1016-1025. https://doi.org/10.1210/jcem-73-5-1016

[17] Nevalainen, M.T., Valve, E.M., Ingleton, P.M., Nurmi, M., Martikainen, P.M., et al. (1997) Prolactin and Prolactin Receptors Are Expressed and Functioning in Human 
Prostate. Journal of Clinical Investigation, 99, 618-627. https://doi.org/10.1172/JCI119204

[18] Reiter, E., Hennuy, B., Bruyninx, M., Cornet, A., Klug, M., et al. (1999) Effects of Pituitary Hormones on the Prostate. Prostate, 38, 159-165.

https://doi.org/10.1002/(SICI)1097-0045(19990201)38:2<159::AID-PROS10>3.0.CO ;2-5

[19] Van Coppenolle, F., et al. (2001) Effects of Hyperprolactinemia on Rat Prostate Growth: Evidence of Androgen Dependence. American Journal of Physiology-Endocrinology and Metabolism, 280, E120-E129. https://doi.org/10.1152/ajpendo.2001.280.1.E120

[20] Wennbo, H., Kindblom, J., Isaksson, O.G. and Tornell, J. (1997) Transgenic Mice Overexpressing the Prolactin Gene Develop Dramatic Enlargement of the Prostate Gland. Endocrinology, 138, 4410-4415. https://doi.org/10.1210/endo.138.10.5461

[21] Kindblom, J., et al. (2003) Prostate Hyperplasia in a Transgenic Mouse with Prostate-Specific Expression of Prolactin. Endocrinology, 144, 2269-2278. https://doi.org/10.1210/en.2002-0187

[22] Feldman, H.A., Longcope, C., Derby, C.A., Johannes, C.B., Araujo, A.B., Coviello, A.D., et al. (2002) Age Trends in the Level of Serum Testosterone and Other Hormones in Middle-Aged Men: Longitudinal Results from the Massachusetts Male Aging Study. Journal of Clinical Endocrinology and Metabolism, 87, 589-598. https://doi.org/10.1210/jcem.87.2.8201

[23] Sawin, C.T., Carlson, H.E., Geller, A., Castelli, W.P. and Bacharach, P. (1989) Serum Prolactin and Aging: Basal Values and Changes with Estrogen Use and Hypothyroidism. Journal of Gerontology, 44, M131-M135. https://doi.org/10.1093/geronj/44.4.M131

[24] Yamaji, T., Shimamoto, K., Ishibashi, M., Kosaka, K. and Orimo, H. (1976) Effect of Age and Sex on Circulating and Pituitary Prolactin Levels in Human. Acta Endocrinologica (Copenhagen), 83, 711-719. https://doi.org/10.1530/acta.0.0830711

[25] Orwoll, E., Lambert, L.C., Marshall, L.M., Phipps, K., Blank, J., et al. (2006) Testosterone and Estradiol among Older Men. The Journal of Clinical Endocrinology \& Metabolism, 91, 1336-1344. https://doi.org/10.1210/jc.2005-1830

[26] Travison, T.G., Araujo, A.B., Kupelian, V., O’Donnell, A.B. and McKinlay, J.B. (2007) The Relative Contributions of Aging, Health, and Lifestyle Factors to Serum Testosterone Decline in Men. Journal of Clinical Endocrinology and Metabolism, 92, 549-555. https://doi.org/10.1210/jc.2006-1859

[27] Bagatell, C.J. and Bremner, W.J. (1996) Androgens in Men-Uses and Abuses. New England Journal of Medicine, 334, 707-714.

https://doi.org/10.1056/NEJM199603143341107 